\title{
The spatial planning of industrial areas in an urbanized area for cargo, in the development of inland waterway transport
}

\author{
Patrycja Jerzyło ${ }^{1, *}$, Aleksandra Wawrzyńska ${ }^{2}$ \\ ${ }^{1}$ Gdańsk University of Technology, Faculty of Civil and Environmental Engineering, Poland \\ ${ }^{2}$ Gdynia Maritime University, Faculty of Navigation, Poland
}

\begin{abstract}
Spatial planning, taking into account the configuration of the surface, i.e. its shape (relief) and the presence and mutual location of objects and points of characteristic water ports, is a derivative of several natural, economic, market, technical, social and political factors. It depends on the destination port, the planned structure of trade in cargo, the forecasted traffic of ships, passageways, the technology of reloading used, as well as on the anticipated demand for the development of shipping and trade by sea and inland waterway.

The article analyzes the transport accessibility of the Port of Gdynia through the construction of a dock to determine the proposals for improving the conditions of transported cargo.
\end{abstract}

\section{Introduction}

The modern seaport conducts business services in the field of ship and cargo handling and operating in land and sea logistics chains. A comprehensive logistics approach has become the standard of port service activity. Logistics systems form the basis of logistic processes whose temporal and spatial dynamics guarantee the development of networks and transport means used to move cargo from the sender to the recipient.

Seaports are an extremely important element of the transport system, in particular in the aspect of land and sea transport chains. The port is a link between the sea and land transport, it depends on the efficiency of the transport chain. The customer choosing the port for the handling of loads sees it in the context of the entire transport chain. With the increase of the importance of seaports in the integration of transport links, the offer of services provided in the port has been expanded to include integrated logistics services. As a result of the increasing demands of customers nowadays, the seaport is no longer just a reloading center, but has evolved into an integrated service center offering solutions for a comprehensive transport process.

The function of affecting the role of seaports in influencing the economy and the economic development of a country is the exchange of goods. The increase in the number of transshipped cargo in ports results in an increase in the demand for the effective import

\footnotetext{
* Corresponding author: patjerzy1@.pg.edu.pl
} 
and transfer of cargo from port terminals. Port access to a well-developed network of transport connections is a factor that influences the increase of the object's competitiveness. It is related to the state of the back-end infrastructure, depending on the time and cost of transporting cargo to the destination. The investments carried out in the background of the port become important, the implementation of which leads to the improvement of road, railway or inland waterway terminals.

\section{Port Gdynia characteristics}

The Port of Gdynia is one of the largest ports in Poland - it ranks as the third largest, just after the ports of Gdansk and Szczecin. It is located on the Gulf of Gdansk, in the eastern part of the city of Gdynia. The adoption of the act on the construction of the Port of Gdynia in 1922 is considered to be the formal beginning of its activity, while the first vessel was moored in the port in 1923. At present, mainly general cargo is handled at the port, in particular single-unit shipments carried in containers and in the ro-ro system. The port in Gdynia is a so-called feeder port, which means that its activity mainly consists in servicing the feed-and-feed connections and ensuring the changed cargoes change the means of transport. The characteristic feature of the port is very favorable navigational conditions. Easy access from the sea results from the natural cover of the road, which is the Hel Peninsula. Additional advantages of the port in Gdynia are the breakwater with a length of 2.5 kilometers and an entrance with a width of 150 meters and a depth of 14 meters. There are no tides in the port and it is an anti-freezing port. The quays have a length of 17,000 meters and over 11,000 meters are wharfs intended for reloading operations. The total area of the facility is $9,729,508 \mathrm{~m}^{2}$, including warehouses with a total area of $230,000 \mathrm{~m}^{2}$ and storage yards with a size of $400,000 \mathrm{~m}^{2}$.

From the point of view of the competitiveness and development of the Port of Gdynia, the transport accessibility of the facility from the background and foreground is important. Access to the port from the sea is possible through three fairways. The width of the main entrance to the port of Gdynia is $150 \mathrm{~m}$ and allows ships with a maximum permissible draft of 13 meters to enter. The main entrance leads directly to the avant-garde and Pool III. It is possible to reach Pool I and II from the side of the South Canal, while the inner part of the port is accessible from the side of the avant-garde. Permanent nautical connections of the Port of Gdynia consist of line connections with China and the Far East, Arab countries, South America, Africa, the Mediterranean Sea, as well as many countries in Europe [6].

The immediate base of the Port of Gdynia is the Tri-City Metropolitan Area, inhabited by over 1 million residents. It consists of eight cities: Pruszcz Gdański, Gdańsk, Sopot, Gdynia, Rumia, Reda, Wejherowo and Żukowo and adjacent municipalities. The areas of the area are formed by a strip system that extends from Wejherowo to Pruszcz Gdański. There are also strong links with the Hel Peninsula and Puck (from the northern part) and Tczew (from the south) [2].

The investment program implemented in the Gdynia port over the last ten years was an important factor in the development of the facility. In this case, both changes taking place in the infrastructure and the port superstructure as well as investments including back-end infrastructure are important. This mainly applies to road and rail connections leading to / from the port.

In the past and near the Port of Gdynia, a number of projects have been carried out in recent years that have a positive impact on improving the transport accessibility of the port area. In 2005, the construction of the A1 motorway, located in the 6th Trans-European Transport Corridor, was commenced. In subsequent years, further sections of the so-called Amber Highway were built, which allowed obtaining a total length of $446.2 \mathrm{~km}$ in mid2016. The four sections of this highway are currently under construction, while the fifth is 
planned. Completion of the investment will make it possible to travel from the Tri-City to the southern border of Poland in full through fast traffic.

In the scope of the Sectoral Operational Program Transport of the European Union, the construction of the Kwiatkowski Route has been completed, providing a direct connection of the Gdynia port with a network of national and international roads. This investment was of great importance for the development of port terminals mainly due to the possibility of goods leaving the port overland and bypassing urban areas (via the Tri-city ring road to the A1 motorway). Moving from the East Port to the Kwiatkowski Overpass also required the expansion of ul. Janka Wiśniewski. The investment was completed in 2005-2008 [6].

As part of the Operational Program Infrastructure and Environment 2007-2013, projects with a total value of nearly PLN 700 million were carried out at the Port of Gdynia From the point of view of the accessibility of the transport infrastructure of the nearby port, the most important investments were:

- extension of the access infrastructure to the eastern part of the Port of Gdynia: investment located along the IV Port Pool, in the northern part of Śródmieście. The project was aimed at modernizing the connection of the Eastern Port with the international transport network via the A1 motorway, along the following roads: Poland - Janka Wiśniewskiego - Kwiatkowski Route - Tri-city Ring Road. The scope of the investment also included the construction of a parking lot for trucks at the Gdynia Maritime Terminal and OT Port Gdynia. As a result of the actions taken, the time of transporting the loads has been shortened and the safety and smoothness of traffic has been increased.

- development of port infrastructure for servicing ro-ro vessels with road and rail access: the undertaking consisted in the reconstruction of the infrastructure in order to increase the transhipment capacity in the eastern part of the port and cost PLN 101.64 million. As part of the project, the surface of the port quays was more effectively managed, which required the reconstruction of the network of roads and railways as well as the demolition of some facilities. The implementation of the investment contributed to the development of the Gdynia port in the ro-ro technology offer.

- reconstruction of the intermodal railway terminal: a project to increase the competitiveness of the port in the 6th Pan-European TEN-T Corridor (Trans-European Transport Network). Thanks to the expansion of the track system, it was possible to take longer train sets, which had a positive impact on the development of the Gdynia port. The implementation of the investment contributed to the reduction of the number of maneuvering movements of trains with diesel locomotives, which in effect improved the operation of the terminal [5].

Under the IE OP, there was also the development of national rail connections. In 20112015, the CE-65 railway line was modernized between Gdynia and Warsaw. This connection is part of the 6th European Transport Corridor and connects the Baltic countries with countries located in the Balkans and on the Adriatic Sea. In terms of investments, the technical parameters of the railway infrastructure were adapted to the speed of $120 \mathrm{~km} / \mathrm{h}$ in freight traffic and the surface was adjusted to axial load of $225 \mathrm{kN}$. As a result, the capacity of the CE-65 line has been increased and the travel time has been reduced, which is connected with the improvement of the quality of transport and increasing the competitiveness of the railway. Modernization works were also performed on lines 201, 202 and 213 [6].

In recent years, the main pier was also rebuilt in the port in Gdynia, the navigation system was modernized and the Dutch and Pomeranian wharfs were extended, as well as the Southern Pier designed for the reloading of chemicals and liquid fuels. In total, expenditures on investment purchases as well as infrastructure and port superstructure in the years 2000-2016 amounted to over PLN 1.2 billion. In 2016, the Port Authority of 
Gdynia allocated PLN 43.57 million for investments, and repairs, maintenance, operation and inspections cost PLN 24.19 million [2].

\section{Transport accessibility of inland waterway transport}

Three international waterways cross the territory of Poland: E-30, E-40 and E-70. The first one connects the Baltic Sea with the Danube river in Bratislava and includes the Oder from Świnoujście to the Czech border. The second runs through the Vistula, Narew and Bug joining the Baltic Sea with the Dnieper, while the E-70 waterway runs from the Netherlands to Lithuania and Russia and covers the Oder, the Vistula-Oder waterway and the lower Vistula in Poland. Inland navigation routes are divided into so-called classes. The waterway is assigned to a specific class on the basis of the maximum ship parameters allowed for navigation and the minimum clearance under pipelines, bridges and other devices that cross the waterway.

The facilities of inland roads of the Port of Gdynia are waterways of class V and II belonging to the section of the lower Vistula. However, these roads do not lead directly to the port of Gdynia, because they end their run in Gdansk. For this reason, inland waterway transport is a small part of cargo transport from the port of Gdynia, because if it is part of the land-sea transport chain, it is generally included in the intermodal transport.

The lack of a direct inland connection between the Port of Gdynia and the Vistula delta is connected with significant difficulties in transporting cargo by inland navigation. In order to load goods, the inland waterway has to enter the Gulf of Gdansk, then to return to Gdynia port. Transshipment and shipping operations in the Gulf of Gdańsk are subject to restrictions due to hydro-meteorological conditions. This is due to the fact that inland vessels are not adapted to navigation and handling at high waves and strong winds. The above factors mean that for the transport of goods inland from the port of Gdynia, it is necessary to equip the unit with additional navigational and emergency devices and to train the crew in the same way as for a sea-going ship.

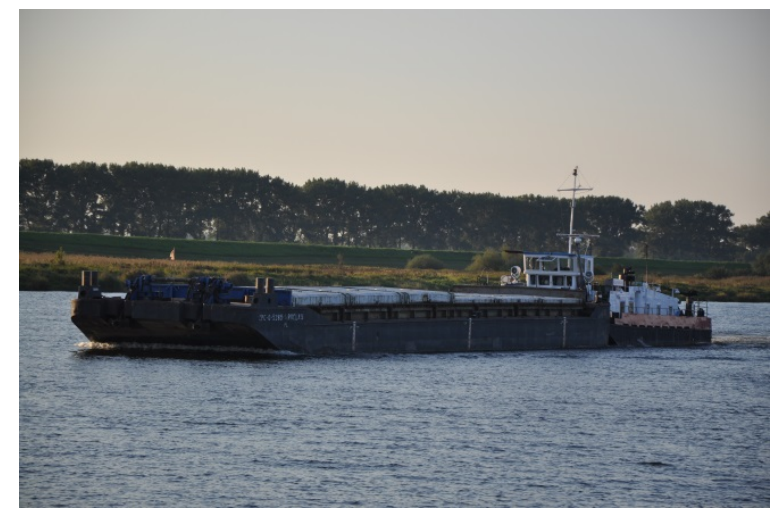

Fig. 1. Inland waterway transport by the Vistula River.

An additional barrier hindering the development of inland waterway transport on the Vistula is the inability to regulate the level of the river on different sections, which means that inland barges cannot transport extremely heavy goods due to the limitation of ship draft and cargo height (insufficient clearance under bridge structures). The transport of goods by the Vistula River is difficult due to the repair and modernization of hydraulic engineering and reloading facilities on which loading and unloading could take place. 
Due to the restrictions described, transport using inland waterway transport is sporadic, and only under favorable conditions (Fig. 1). In many cases it is more cost-effective to choose the transport of freight by rail or road transport [7].

\section{The barge dock in the port of Gdynia}

The implementation of the basic port and economic functions of the seaport depends on the existence of a suitably spatially planned port territory. In port practice, three types of seaborne space development strategies can be distinguished: expansion strategy, rationalization strategy and an indirect approach. In the case of seaports characterized by the expansion strategy, the acquisition of new areas to expand the existing port area becomes the course of action. In many cases, this strategy involves the removal of new areas of the sea, due to the lack of free space for development. However, using the rationalization strategy, port authorities apply the following actions, for example:

- extension of the industrial function of port facilities by carrying out a transport and distribution function for third parties,

- extension of the distribution and logistics function, for example through the implementation of modern logistics in port operations,

- demolition of buildings or landing of port basins,

- construction of a new or modernization of the existing port infrastructure,

- handling new loads or introducing new relations for supported loads.

a)

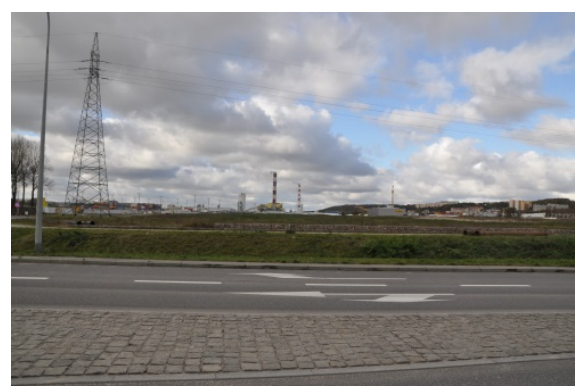

b)

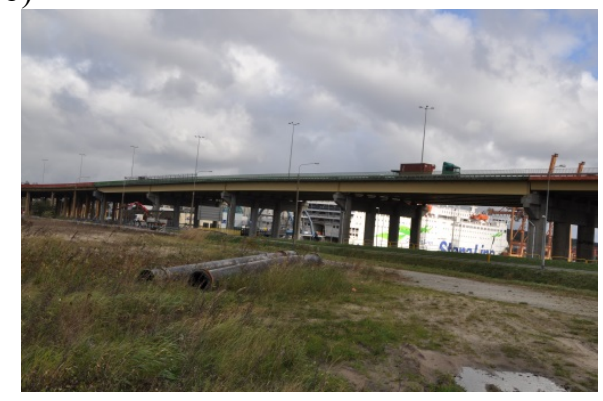

Fig. 3. View of: a) reserve of the Chylonki valley and b) Kwiatkowski Overpass [photo: Patrycja Jerzyło].

Directions for the development of port areas for individual ports are largely intermingled. The revitalization of economically depleted port areas is associated with the need to develop new areas. In Polish ports, activities related to the revitalization strategy are currently being implemented to a large extent. Restructuring processes taking place in port areas in Poland are based on both the development of urban-port functions and other functions. Examples of activities in this area are the universalisation of the service offer or the reconversion of sites that serve a given type of cargo for other types of land. Some Polish ports had the opportunity to develop new areas through expansion. In this way, the area of the external port in Gdansk was increased and the ferry base in Świnoujście was expanded. In these ports, new areas were also acquired by going out to sea, the DCT terminal in Gdańsk and the LNG terminal in Świnoujście. However, it is important that in most Polish ports the newly acquired areas were not located near the main port areas. Due to the ending of free space for the development of ports, the future directions of port development are mainly related to restructuring, but the acquisition of new areas for investment is most difficult in the Gdynia port, where the only possible action in the field of 
spatial development is the revitalization of previously used areas [4]. An exception is the area reserved for the construction of a barge dock in Gdynia (reserve of the Chylonki valley).

In the container base project, the planned port basin is in the Chylonki Valley behind the Kwiatkowski Bridge. The water reservoir, which can be pulled under the bridge, can be used not only for barges and pontoons, but also for other port auxiliary units [1].

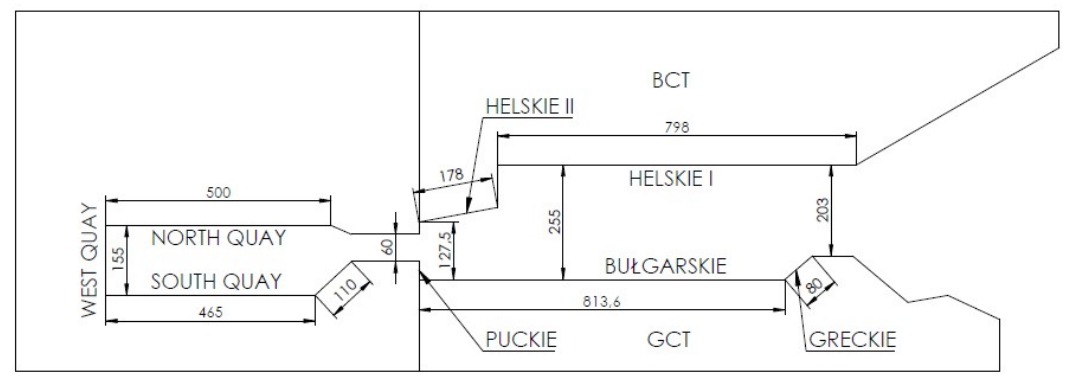

Fig. 3. Construction project of the barge dock in the port of Gdynia [Own study based on 3].

The barge basin is designed as the last opportunity to expand the Gdynia harbor area inland. This basin is indented into terrain with ordinates from $0.0 \mathrm{~m}$ to about $9.5 \mathrm{~m}$ above sea level. and has limited reloading and storage capabilities. Design parameters of the shoulder dock (Fig. 3): width $150 \mathrm{~m}$, length approx. $500 \mathrm{~m}$ and depth $6.0 \mathrm{~m}$. The limit for units will be the clearance under the Kwiatkowski Ovepass amounting to $17.4 \mathrm{~m}$. An access canal has also been designed for a pool with a width of $60.0 \mathrm{~m}$ (Figure 4). [3]

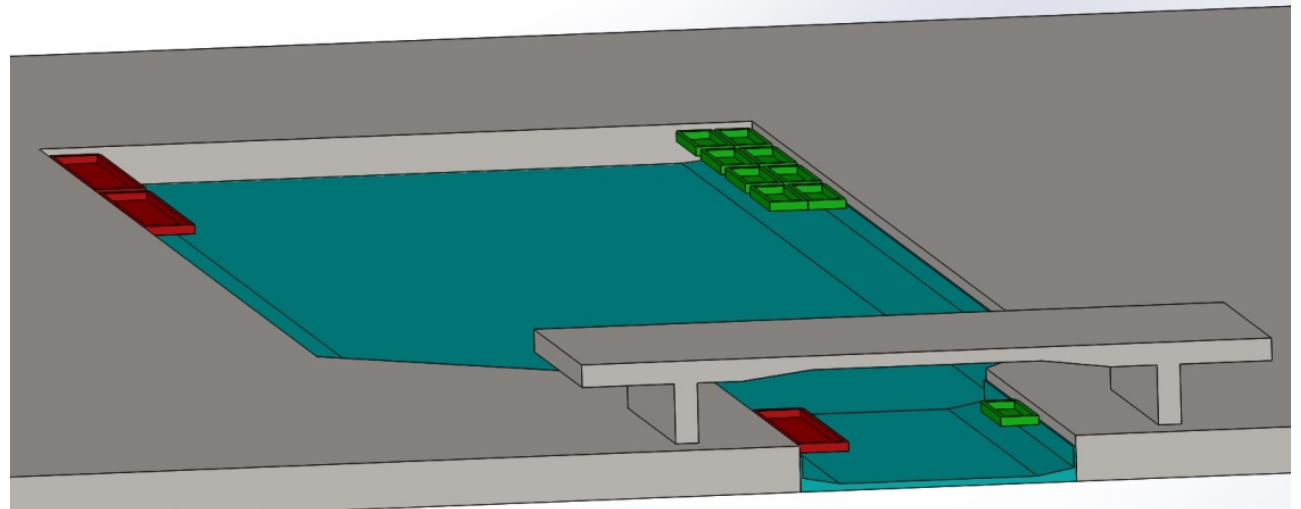

Fig. 4. Model of the barge dock in the Port of Gdynia [Own study based on 3].

\section{Summary}

The considerations made have made it possible to specify the importance of an efficient transport system for the effective operation of not only the port terminals of the Port of Gdynia, but also the entire transport chain. Both the volume of transshipment turnover, financial statistics and the competitiveness of the Gdynia port against the background of other transhipment hubs of the Baltic Sea are strictly dependent on the standard of back office connections. Detailed examination of the road, railway and inland waterway network in the near vicinity of the Port of Gdynia and the directions of the development of the 
facility and its access infrastructure made it possible to assess the potential of transporting goods in the port.

The analysis carried out showed that inland navigation is the least developed and yet has the greatest development potential, the branch of transport at the back of the Port of Gdynia. This is mainly due to the fact that in the close vicinity of the Gdynia port there is the Vistula River and several of its tributaries, and the construction of an intermodal terminal in Zajączkowo Tczewskie is planned. Many investment projects that facilitate inland transport at the back of the port in Gdynia are feasible.

Lack of direct inland water connection between the Port of Gdynia and the Vistula delta transport of port goods by means of barges is significantly impeded. The carriage of cargo by inland water requires the ship to enter the Gulf of Gdańsk, which requires the necessity of equipping it with appropriate rescue and navigation devices, as well as additional training of the crew. An important factor limiting the development of inland waterway transport is the fact that the Vistula is a very unregulated river. For this reason, inland vessels can't transport heavier goods because the draft is limited. Despite numerous difficulties, the potential of inland transport development at the back of the Gdynia port is large. Many investments aimed at increasing the accessibility of the Tri-City water and improving the conditions of navigation on the international E-70 waterway are planned. Improvements are to take place mainly through activities leading to the adaptation of the Vistula to the standards set out in the AGN Convention. If the planned activities are implemented in the coming years, the quality of the Gdynia Port service using inland waterway transport will be significantly improved.

Transport availability of the facilities of the near Gdynia port has a key impact on the port's competitiveness and its further development. There are many possibilities to ensure the improvement of access to the back-up road, rail and inland infrastructure. With the completion of relevant investment projects, port terminals will gain an extensive and modern infrastructure, tailored to the market needs in the field of cargo handling.

\section{References}

1. W. Andruszkiewicz, Wytyczne $w$ zakresie przyszłościowego wykorzystania $i$ zagospodarowania terenów portowych i przyportowych w Gdyni, Instytut Morski, Gdańsk-Szczecin (1973)

2. T. Boheński, T. Palmowski: Polskie porty morskie i rola kolei $w$ ich obstudze na przełomie XX i XXI wieku, Gdańsk, (2015)

3. Projmors, Studium technologiczno-urbanistyczne docelowej rozbudowy Bazy Kontenerowej przy nabrzeżu Helskim w porcie Gdynia , (1979)

4. M. Pluciński: Teoretyczne i praktyczne aspekty zagospodarowania przestrzeni współczesnych portów morskich ze szczególnym uwzględnieniem portów morskich o podstawowym znaczeniu dla gospodarki Polski, Logistyka, Poznań (2014)

5. [Online] Available: http://www.port.gdynia.pl/pl//. [Accessed: 22-Feb-2018]

6. [Online] Available: http://www.plk-inwestycje.pl/inwestycje/program-operacyjnyinfrastruktura-i-srodowisko/poiis-71-12///. [Accessed: 05-March-2018]

7. [Online] Available: https://pl.wikipedia.org/wiki/Śródlądowe_drogi_wodne [Accessed: 12-March-2018] 